\title{
Ampulla of Vater Cancer TNM Finding v7
}

National Cancer Institute

\section{Source}

National Cancer Institute. Ampulla of Vater Cancer TNM Finding v7. NCI Thesaurus.

Code C90264.

A finding about one or more characteristics of ampulla of Vater cancer, following the rules of the TNM AJCC V7 classification system. 